\title{
Effects of GnRH antagonist treatment on follicular development and angiogenesis in the primate ovary
}

\author{
P D Taylor ${ }^{1,2}$, S G Hillier ${ }^{2}$ and H M Fraser ${ }^{1,2}$ \\ ${ }^{1}$ Medical Research Council Human Reproductive Sciences Unit, 49 Little France Crescent, Edinburgh EH16 4SB, UK \\ ${ }^{2}$ University of Edinburgh Centre for Reproductive Biology, 49 Little France Crescent, Edinburgh EH16 4SB, UK \\ (Requests for offprints should be addressed to H M Fraser, Medical Research Council, Human Reproductive Sciences Unit, 49 Little France Crescent, \\ Edinburgh EH16 4SB, UK; Email: h.fraser@hrsu.mrc.ac.uk)
}

\begin{abstract}
Angiogenesis is required for normal follicular development but the role of gonadotrophins in the control of follicular angiogenesis remains to be elucidated. This study investigated the effects of treatment with GnRH antagonist in vivo on follicular development and angiogenesis in the marmoset. GnRH antagonist was administered on either follicular day 0 or day 5 of the 10-day follicular phase with ovaries collected on day 10 . Ovaries from control marmosets were studied at day 5 (mid follicular phase) and day 10 (periovulatory period). Ovaries were fixed, serial sectioned and subjected to morphological analysis and immunocytochemistry to determine cell proliferation and follicular endothelial cell area and in situ hybridization to assess changes in expression of vascular endothelial growth factor (VEGF). Treatment with GnRH antagonist from day
\end{abstract}

0-10 resulted in an absence of dominant preovulatory follicles seen in controls. In the remaining tertiary follicles granulosa, theca and endothelial cell proliferation was reduced, resulting in a minor reduction in vascular density. However, VEGF mRNA expression was unaffected by treatment. Treatment from day 5-10 did not prevent development of ovulatory size follicles, but they were atretic and lacked VEGF mRNA. These results suggest that while VEGF expression in the preovulatory follicle is under gonadotrophic control it is not dependent on normal gonadotrophin secretion in tertiary follicles, indicating that there are other paracrine factors regulating VEGF expression in the developing ovarian follicle.

Journal of Endocrinology (2004) 183, 1-17

\section{Introduction}

The ovary is one of few organs in the body to undergo serial angiogenesis which is intimately involved in ovarian follicle development (Fraser \& Wulff 2001, Wulff et al. 2001b, 2002, Zimmermann et al. 2001, 2003). Angiogenesis in the ovarian follicle is restricted to the thecal compartment, the resulting capillaries forming a vascular sheath around the growing follicle that continues to develop during folliculogenesis (Wulff et al. 2001b). The new blood vessels associated with dominant follicles do not penetrate the membrana propria, leaving the granulosa cells of the follicles avascular until the point of ovulation at which time the basement membrane breaks down. The degree of vascularization achieved has been hypothesized to be involved in the establishment of follicle dominance (Zeleznik et al. 1981), facilitating the delivery of gonadotrophins, steroid precursors, oxygen and nutrients from the blood stream, but whether an abundant vasculature is a cause or consequence of follicle dominance remains to be determined.

The principal angiogenic factor with an established role in follicular angiogenesis is vascular endothelial growth factor (VEGF). VEGF mRNA and protein have been localized in the ovary to the granulosa cells of the developing follicles and the theca of preovulatory follicles (Phillips et al. 1990, Ravindranath et al. 1992, Shweiki et al. 1993). Inhibition of VEGF in vivo in the marmoset monkey has been shown to severely suppress both thecal vascularization and follicle development (Wulff et al. $2001 b, 2002)$ and to inhibit the follicular phase of the cycle in macaques (Zimmermann et al. 2001, 2002).

VEGF is expressed in the granulosa and thecal cells of follicles as they mature and is concurrent with the acquisition of steroidogenic activity, suggesting that the expression is hormonally regulated (Shweiki et al. 1993). It has also been demonstrated that VEGF expression in granulosa cells is up-regulated by follicle-stimulating hormone (FSH) stimulation in vitro (Christenson \& Stouffer 1997, Hazzard et al. 1999). In the current study, the role of the gonadotrophins was assessed by administration of a gonadotrophin-releasing hormone $(\mathrm{GnRH})$ antagonist in vivo during follicular development in the marmoset, a species in which we have described the development of the follicular vasculature in detail (Wulff et al. 2001b, 
2002). Since it is established that GnRH antagonist treatment suppresses follicular development by inhibiting both FSH and luteinizing hormone (LH) secretion from the pituitary (Fluker et al. 1991, Hall et al. 1991, Fraser et al. 1999b), the aim of the present study was to test the hypothesis that this suppression resulted in a reduced production of follicular VEGF mRNA with resultant inhibition of angiogenesis. The effects of the antagonist on follicular angiogenesis were examined using bromodeoxyuridine (BrdU) immunocytochemistry as a proliferation marker, CD31 as an endothelial specific cell marker and dual staining to distinguish proliferating endothelial cells. Effects of treatment on expression of VEGF and aromatase mRNA were determined by in situ hybridization.

\section{Materials and Methods}

\section{Animals}

Adult female common marmoset monkeys (Callithrix jacchus), 2-3 years old with a body weight of approximately $350 \mathrm{~g}$ and regular (28-day) ovulatory cycles, as determined by plasma progesterone concentrations on blood samples collected three times per week (Wulff et al. 2001c), were housed together with a younger sister or prepubertal female, as described previously (Fraser et al. 1999a).

\section{Treatment}

Experiments were carried out in accordance with the Animals (Scientific Procedures) Act 1986, and were approved by the Local Ethical Review Process Committee. To synchronize the timing of ovulation, marmosets were treated with $1 \mu \mathrm{g}$ prostaglandin $(\mathrm{PG}) \mathrm{F}_{2 \alpha}$ analogue (cloprostenol, Planate; Coopers Animal Health Ltd, Crewe, Cheshire, UK), intramuscularly on days 12-15 of the 20-day luteal phase to induce luteolysis. The day of PG injection was designated follicular day 0 . This regime was based upon that of Gilchrist et al. (2001), who have described detailed changes in follicular populations during the subsequent follicular phase. We employed the GnRH antagonist Antarelix (Deghenghi et al. 1993), $\left[\mathrm{N}-\mathrm{Ac}-\mathrm{D}-\mathrm{Nal}{ }^{1}, \mathrm{D}-\mathrm{pCl}-\mathrm{Phe}^{2}, \mathrm{D}-\mathrm{Pal}{ }^{3}, \mathrm{D}-(\mathrm{Hci})^{6}, \mathrm{Lys}(\mathrm{iPr})^{8}, \mathrm{D}-\right.$ $\left.\mathrm{Ala}^{10}\right] \mathrm{GnRH}$ (Europeptides, Argenteuil, France) dissolved in water to a concentration of $10 \mathrm{mg} / \mathrm{ml}$. To provide a slow-release depot Antarelix was administered at a dose of $12 \mathrm{mg} / \mathrm{kg}$, injected subcutaneously on follicular day $0(n=4)$ or follicular day $5(n=6)$. Ovaries from the treated animals were collected 10 days after PG administration, corresponding to the periovulatory period in control animals. Control marmosets were studied on day 0 $(n=3)$, day $5(n=4)$ and day $10(n=6)$ relative to PG administration. After PG administration, blood samples continued to be collected from the animals three times a week to monitor progesterone levels. All animals were injected i.v. with $20 \mathrm{mg}$ BrdU (Roche Molecular Biochemicals, Essex, UK) in saline $1 \mathrm{~h}$ before being sedated using $100 \mu \mathrm{l}$ ketamine hydrochloride (Parke-Davis Veterinary, Pontypool, Gwent, UK) and killed with an i.v. injection of $400 \mu \mathrm{l}$ Euthetal (sodium pentobarbitone; Rhone Merieux, Harlow, Essex, UK). After cardiac exsanguination, ovaries were removed, weighed and immediately fixed in $4 \%$ neutral buffered formalin. After $24 \mathrm{~h}$, the ovaries were transferred to $70 \%$ ethanol, dehydrated and embedded in paraffin according to standard procedures.

To confirm the potency of the GnRH antagonist treatment, three marmosets with regular cycles were given the treatment described above, but allowed to recover normal cycles as determined by measuring plasma progesterone in blood samples collected three times per week.

\section{Steroid assays}

Oestradiol concentrations in serum collected by exsanguination were determined by an ELISA assay adapted from Mann et al. (1995). The detection limit for the assay was $1 \mathrm{ng} / \mathrm{l}$. Interassay coefficients of variation for low, medium and high quality controls were $15 \cdot 5 \%, 6 \cdot 5 \%$ and $6.4 \%$ respectively. All samples were run in a single assay. Plasma progesterone concentrations were determined by an ELISA assay, as previously described (Wulff et al. 2001c).

\section{Morphological characterization of ovarian follicles}

Stages of follicular development were defined as follows: primary (oocyte surrounded by one granulosa cell layer), early secondary (two to four granulosa cell layers, no antrum), late secondary (more than four granulosa cell layers, no antrum), tertiary (follicles containing an antrum) and ovulatory (large antral follicles $>2 \mathrm{~mm}$ ). Follicles were classified as healthy if they contained a normal-shaped oocyte surrounded by granulosa cells that were regularly apposed on an intact basement membrane with normal appearance of granulosa cell nuclei without signs of pycnosis. Follicles were classified as atretic when they showed signs of granulosa cell pycnosis, the first morphological sign of follicular atresia (Durlinger et al. 2000). Only follicles with a visible oocyte containing a nucleus were considered to ensure proper follicular classification. Follicles not fulfilling these criteria were classified as unsuitable for analyses.

\section{Haematoxylin-eosin staining}

The embedded ovaries were serially sectioned, and tissue sections $(5 \mu \mathrm{m})$ were placed onto BDH SuperFrost 
slides (BDH, Merck Co., Inc., Poole, Dorset, UK). For morphological and morphometric analyses every 40th section of the ovaries was used. Sections in between were subjected to immunocytochemistry and in situ hybridization. Sections were dewaxed in xylene, rehydrated in descending concentrations of ethanol, washed in distilled water and stained with haematoxylin (Richard-Allan, Richland, MI, USA) for $5 \mathrm{~min}$, followed by a wash in water and acetic alcohol before staining with eosin (Richard-Allan) for $20 \mathrm{~s}$. After dehydrating in ascending concentrations of ethanol and xylene, sections were mounted.

\section{Immunocytochemistry}

The effects of the treatment on the establishment of the thecal vascular network were studied by (1) quantifying the number of proliferating cells stained for BrdU, (2) identifying endothelial cells using CD31 staining and (3) distinguishing proliferating endothelial from nonendothelial cells by colocalization of BrdU and CD31.

For BrdU and CD31 immunostaining, antigen retrieval was performed by pressure cooking (Tefal Clypso pressure cooker; Tefal, Langley, Berks, UK) sections in 0.01 M citrate buffer, $\mathrm{pH} 6$, for 6 min at high pressure setting 2 . Slides were then left for $20 \mathrm{~min}$ in hot buffer and washed in Tris-buffered saline (TBS; $0.05 \mathrm{~mol} / \mathrm{l}$ Tris and $9 \mathrm{~g} / \mathrm{l}$ $\mathrm{NaCl})$. To reduce non-specific binding, sections were blocked in normal rabbit serum (NRS; 1:5 diluted in TBS containing $5 \%$ bovine serum albumin) for $30 \mathrm{~min}$. Primary antibodies CD31 (mouse anti-human CD31; DAKO Corp., Copenhagen, Denmark) or BrdU (mouse antiBrdU; Roche Molecular Biochemicals) were diluted 1:20 or 1:30 in TBS respectively. Incubation was carried out overnight at $4{ }^{\circ} \mathrm{C}$. Slides were washed three times in TBS. Incubation with the secondary antibody, rabbit anti-mouse Ig (1:60 diluted in NRS:TBS; DAKO Corp.), was performed for $40 \mathrm{~min}$ at room temperature, followed after two washes in TBS by incubation of the alkaline phosphatase-anti-alkaline phosphatase complex (1:100 dilution in TBS; DAKO Corp.) for $40 \mathrm{~min}$ at room temperature. Visualization was performed using $500 \mu \mathrm{l} /$ slide nitro blue tetrazolium (NBT) solution containing $45 \mu \mathrm{l}$ NBT substrate (Roche Molecular Biochemicals), $10 \mathrm{ml}$ NBT buffer, $35 \mu \mathrm{l}$ 5-bromo-3-chloro-3-indolylphosphate and $10 \mu \mathrm{l}$ levamisole. Sections for BrdU were counterstained with haematoxylin, whereas sections for CD31 were not counterstained, so that quantitative image analysis could be performed. For dual labelling, slides were incubated first with CD31 and visualized with Fast Red (Sigma, Poole, Dorset, UK); $1 \mathrm{mg}$ Fast Red in $1 \mathrm{ml}$ Fast Red buffer (20 mg 3-hydroxy-2-naphthoic acid 2,4dimethylamide phosphate, $2 \mathrm{ml}$ dimethyl formamide and

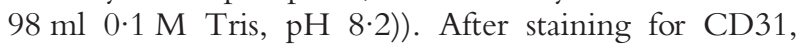
incubation with BrdU was performed. BrdU-stained cells were visualized with NBT as described above.

\section{Quantification of immunocytochemistry}

It was previously demonstrated that angiogenesis is initiated in follicles containing more than four granulosa cell layers (Wulff et al. 2001b). Thus, in this study, only follicles with four or more granulosa cell layers were analysed. Captured images were thresholded, and the thecal and granulosa cell compartments were outlined and analysed separately. Four sections per ovary were analysed under $\times 200$ magnification. Cellular proliferation was measured using an image analysis system set up to measure the number of dark-stained nuclei (BrdU positive), and the number of dark- and light-stained nuclei (total number of cells) in the outlined compartment of interest. A proliferation index (BrdU-positive cells expressed as a percentage of the total number of cells) was calculated in the thecal and granulosa compartments for each follicle. The proliferation index is expressed as a mean value for the number of follicles assessed within each follicular stage and per animal.

The automated image analysis of $\mathrm{BrdU}$ in the granulosa of secondary follicles failed to reliably distinguish between single cells because granulosa cells have only a small cytoplasmic volume, so that the nuclei of different cells are in close vicinity. Thus, the granulosa cell proliferation index in these follicles was obtained by manual counting of the number of granulosa cells and the granulosa cell area from 50 secondary follicles, calculating a mean cell number per unit area and measuring granulosa cell area and converting the area to cell number.

The endothelial cell area (CD31-positive cells) was measured by thresholding a captured grey scale image and converting it to a binary image. The whole area of the thecal compartment and the CD31-positive area within the compartment were measured. The CD31-positive area was then calculated per unit area of the thecal compartment and expressed as a mean value for the number of follicles assessed within each follicular stage and per animal.

Proliferating endothelial cells (dual-stained cells) were counted manually at $\times 200$. Only endothelial cells (red stain) that were also BrdU positive (black stain) were counted as proliferating endothelial cells. Non-endothelial cell proliferation was calculated by multiplying the total thecal proliferation index (BrdU count) by the percentage of proliferation that was not endothelial (not dual-stained, BrdU-positive cells on a dual-stained slide) per animal. Quantitative analysis was performed using an image analysis system linked to an Olympus Corporation camera, and the data were processed using Image-Pro Plus version 3.0 for Windows (Microsoft).

\section{In situ hybridization}

In situ hybridization was performed as described previously (Fraser et al. 2000, Wulff et al. 2001c). As the marmoset 
Table 1 The number of follicles from each follicular class and each treatment group measured for each immunocytochemical and in situ analysis

\begin{tabular}{|c|c|c|c|c|c|c|c|c|c|c|c|c|c|c|}
\hline & \multicolumn{3}{|c|}{ BrdU } & \multicolumn{3}{|c|}{ CD31 } & \multicolumn{3}{|c|}{ Dual } & \multicolumn{4}{|c|}{ VEGF mRNA } & \multirow{2}{*}{$\frac{\text { Aromatase mRNA }}{\text { Dom }}$} \\
\hline & LS & $\mathrm{T}$ & Dom & LS & $\mathrm{T}$ & Dom & LS & $\mathrm{T}$ & Dom & LS & $\mathrm{T}$ & Dom & A & \\
\hline LF control & 105 & 33 & 9 & 23 & 27 & 9 & 29 & 24 & 9 & 10 & 18 & 9 & 28 & 7 \\
\hline GnRH antag 0-10 & 24 & 17 & & 21 & 20 & & 25 & 25 & & 5 & 16 & & 7 & \\
\hline GnRH antag 5-10 & 55 & 34 & 8 & 27 & 21 & 8 & 27 & 23 & 8 & 14 & 29 & 7 & 14 & 7 \\
\hline MF control & & & & & & & & & & 2 & 23 & & 14 & \\
\hline
\end{tabular}

LF, late follicular phase; MF, mid follicular phase; GnRH antag 0-10, GnRH antagonist treatment on day 0-10; GnRH antag 5-10, GnRH antagonist treatment on day $5-10$.

shows very close homology of the known human gene sequence, a cRNA probe for human VEGF probe was used. For aromatase, a marmoset-specific cRNA probe was generated. Sense and antisense probes were prepared using an RNA transcription kit (Ambion, Inc. Austin, TX, USA) and were labelled with $\left[{ }^{35}\right.$ S] uridine $5^{\prime}-$ triphosphate (NEN Life Science Products, Boston, MA, USA). Deparaffinized sections were treated with $0 \cdot 1 \mathrm{M}$ $\mathrm{HCl}$ and then digested in proteinase $\mathrm{K}(5 \mu \mathrm{g} / \mathrm{ml}$; Sigma $)$ for $30 \mathrm{~min}$ at $37^{\circ} \mathrm{C}$. After prehybridization for $2 \mathrm{~h}$ at $55^{\circ} \mathrm{C}$ subsequent hybridization was performed in a moist chamber overnight. High stringency post-hybridization washings and ribonuclease treatment were used to remove excess probe. Slides were then dehydrated, dried and dipped in Ilford G5 liquid emulsion (H A West, Edinburgh, UK) and exposed for 3 weeks. Slides were subsequently developed (D19 developer; Kodak, Rochester, NY, USA) and fixed (GBX fixer; Kodak). All slides were counterstained with haematoxylin (Richard-Allan), dehydrated and mounted.

In situ slides were analysed blind by two investigators separately. A scoring system of $0=$ no hybridization above background, $+=$ detectable but low grain density clearly above background levels, $++=$ moderate grain density and $+++=$ high grain density was employed to denote the level of hybridization observed in each follicle and the results were compared for agreement.

\section{Statistical analysis}

Data obtained for different cycle and follicular stages were tested for significant differences using ANOVA. Effects of the treatment compared with late follicular controls were determined using a two-tailed, unpaired $t$-test. In situ analysis was tested for significant differences using the Kruskal-Wallis test. Differences were considered to be significant at $P<0 \cdot 05$. The tests were performed using SPSS version 11 for Macintosh (SPSS, Inc., Chicago, IL. USA). All values are given as the mean \pm S.E.M. Table 1 details the number of follicles analysed for each follicular class and stain.

\section{Results}

\section{Hormonal changes}

All marmosets responded to PG with a rapid fall in plasma progesterone concentration that remained at follicular phase levels for the duration of the study. Treatment suppressed serum oestradiol-17 $\beta$ levels, consistent with inhibition of gonadotrophin release, significant reductions being observed between late follicular controls and both treatment groups (day $0-10 P=0 \cdot 022$, day $5-10 P=0 \cdot 027$ ) (Fig. 1). Additional evidence for potency of the $\mathrm{GnRH}$ antagonist treatment was demonstrated in animals left to recover after a single $12 \mathrm{mg} / \mathrm{kg}$ injection of Antarelix. Ovulation was suppressed and a progesterone rise was not observed until between 80 and 110 days after treatment (data not shown).

\section{Ovarian morphology}

In a cross-section through a typical control ovary at days $12-15$ of the luteal phase, the time of PG injection

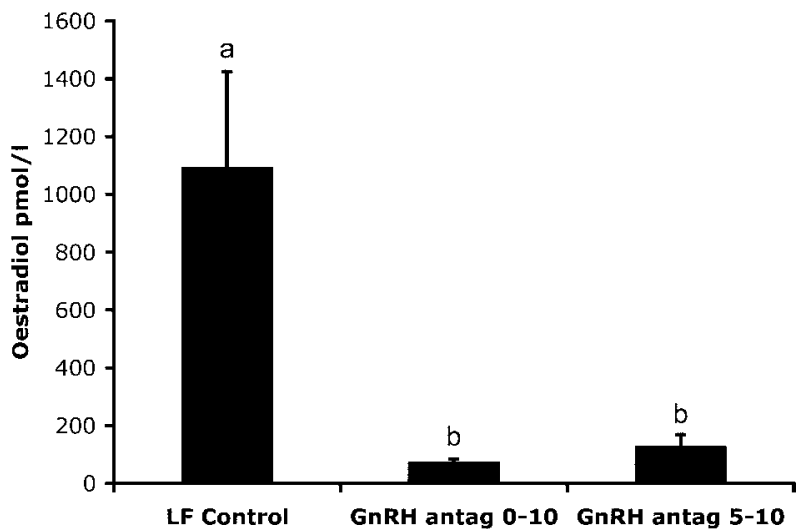

Figure 1 Plasma oestradiol levels in control marmosets at day 10 of the follicular phase (LF) and after treatment with $\mathrm{GnRH}$ antagonist between day 0-10 (GnRH antag 0-10) or 5-10 (GnRH antag 5-10). Oestradiol levels were significantly reduced by both of the treatments. Values are means \pm S.E.M. Different letters indicate statistically significant differences. 


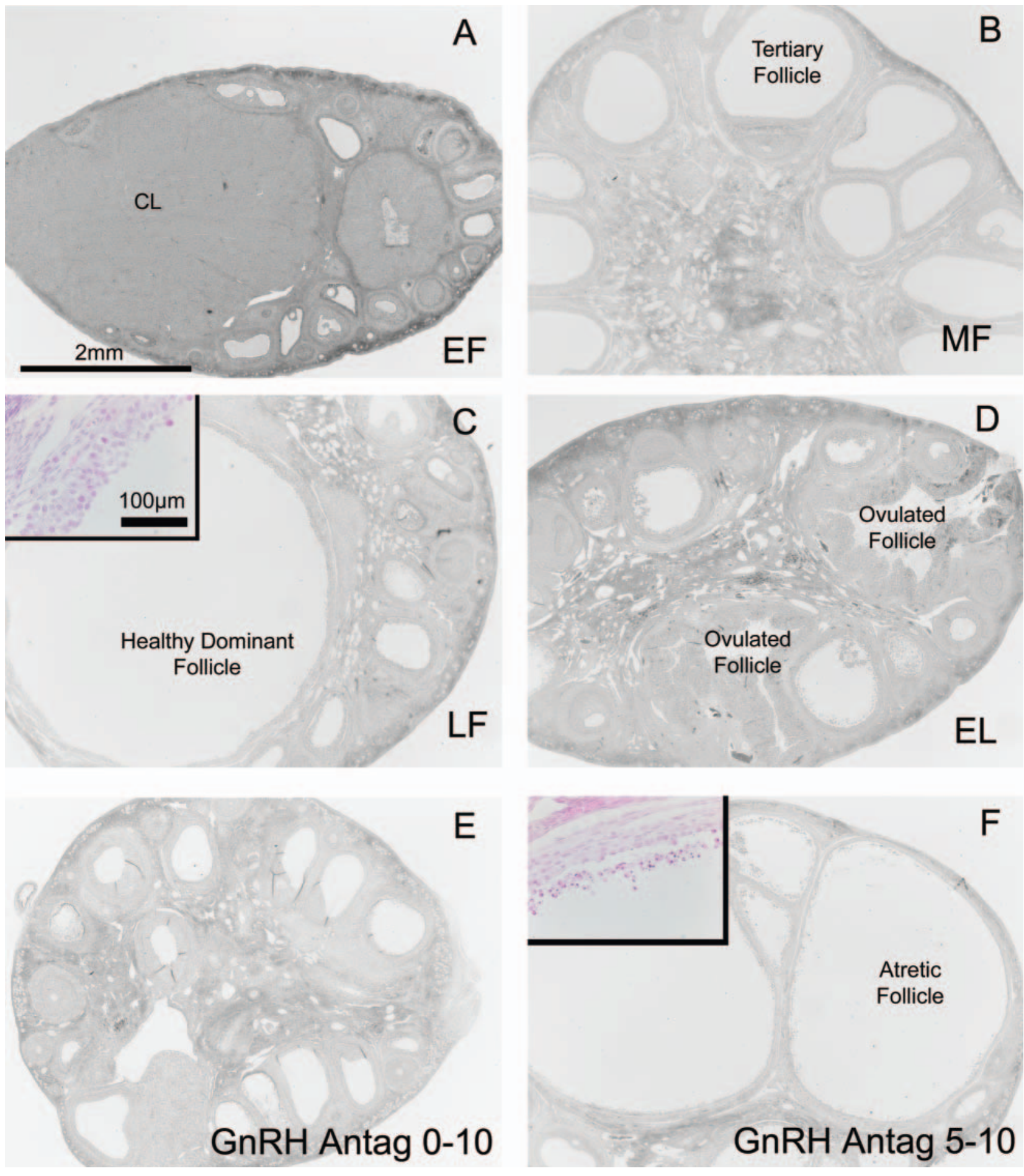

Figure 2 Haematoxylin and eosin-stained sections of (A) control early follicular phase (EF), representative of days 14-16 of the luteal phase $(C L=$ corpus luteum), (B) mid follicular phase (MF) with tertiary follicles, (C) late follicular phase (LF) with healthy dominant follicles containing intact granulosa cells (inset), (D) early luteal phase (EL), (E) GnRH antagonist (Antag) treatment day 0-10 and (F) GnRH antagonist treatment day 5-10 showing atretic granulosa cells (inset). Note the lack of healthy dominant follicles in both of the treated groups. 
(Fig. 2A), the corpus luteum was the dominant tissue in the organ, accompanied by numerous small and medium sized antral follicles. By day 5 after PG injection, the mid follicular phase (Fig. 2B), the corpus luteum had regressed as a result of PG treatment, and many healthy and atretic tertiary follicles dominated the ovary. In the day $10 \mathrm{control}$ ovaries, the periovulatory period, the predominant feature was either the presence of one to three healthy dominant follicles together with a combination of atretic and small antral follicles ( $n=3$ marmosets) (Fig. 2C) or collapsed follicles indicating that ovulation had just occurred in the remaining three animals (Fig. 2D).

Both of the treatment schedules significantly reduced paired ovary weight; day $0-10(103 \pm 21 \mathrm{mg})$, day $5-10$ $(109 \pm 8 \mathrm{mg})$ compared with a mean day 10 control weight of $(165 \pm 22 \mathrm{mg})$. After $\mathrm{GnRH}$ antagonist treatment between day $0-10$ of the follicular phase, there was no evidence of dominant follicle development or freshly ovulated follicles although tertiary follicles were present (Fig. 2E). In contrast, after GnRH antagonist treatment between days 5 and 10 of the follicular phase, there were follicles of preovulatory size present in the ovaries, but these follicles were atretic (Fig. 2F). Again tertiary and atretic follicles were also observed.

\section{Effect on tertiary follicle development}

Frequency measurements of follicle populations are shown in Fig 3. Healthy follicles with diameters $>2000 \mu \mathrm{m}$ present in controls (Fig. 3A) were absent in both treatment groups (Fig. 3B and $\mathrm{C}$ ). The mean diameter of the remaining tertiary follicles in late follicular control ovaries was $680 \mu \mathrm{m}$. After GnRH antagonist, the mean follicle diameter increased to $767 \mu \mathrm{m}$ and $736 \mu \mathrm{m}$ for treatment between day $0-10$ and day $5-10$ respectively. Comparison of the mean diameter (Fig. 3D) confirmed a significant increase $(P=0.048)$ in mean tertiary follicle (excluding dominant) diameter after $\mathrm{GnRH}$ antagonist treatment between day 0-10 compared with controls.

The number of atretic antral follicles (Fig. 3E) was significantly decreased in both the treatment groups compared with late follicular controls (day 0-10 $P=0.007$ and day 5-10 $P=0 \cdot 044$ ). Atretic dominant follicles (Fig. 3F) were unique to the days $5-10 \mathrm{GnRH}$ antagonist treatment group.

\section{Effect on cellular proliferation}

The total number of proliferating cells was counted as a percentage of the total number of cells present in the follicle compartment in question. Comparison of a section from the wall of a typical tertiary follicle from a late follicular control (Fig. 4A), a GnRH antagonist-treated ovary from day 0-10 (Fig. 4B) and a GnRH antagonisttreated ovary from day 5-10 (Fig. 4C) revealed a decrease in both granulosa and thecal proliferation after both treatment schedules. Quantitative analyses confirmed significantly decreased cell proliferation in both granulosa (day 0-10 $P=0.013$ and day 5-10 $P=0.009$ ) and theca (day $0-10 P=0.034$ and day $5-10 P=0.029$ ) of tertiary follicles after treatment compared with late follicular controls (Fig. 4D). In the dominant follicles, a significant reduction in cellular proliferation in the theca $(P=0 \cdot 01)$ and granulosa $(P=0.044)$ compartments was also seen after GnRH antagonist treatment between day 5-10 of the follicular phase compared with late follicular controls (Fig. 4E).

\section{Endothelial cell proliferation}

An index of the number of proliferating cells in the thecal compartment that were endothelial cells by co-localization of CD31 and BrdU was used to determine the extent to which the treatment had impaired endothelial cell division and hence ongoing angiogenesis. In late follicular control ovaries (Fig. 5A), dual-labelled cells were readily apparent. In tertiary follicles from ovaries from $\mathrm{GnRH}$ antagonist treatment between day 0-10 dual-labelled cell were reduced significantly $(P=0 \cdot 043)$. After treatment between day 5-10 (Fig. 5C), there was a non-significant reduction in dual-labelled cells. Endothelial cell proliferation was also significantly reduced $(P=0.036)$ between dominant but atretic follicles from the day 5-10 GnRH antagonist treatment group and dominant follicles from late follicular controls (Fig. 5D).

The amount of non-endothelial, presumably predominantly thecal, cell proliferation in the theca was also examined (data not shown). GnRH antagonist treatment between day $0-10$ resulted in a significant $49 \%(P=0 \cdot 029)$ reduction in the number of non-endothelial cells proliferating in tertiary follicles compared with late follicular controls. GnRH antagonist treatment from day 5-10 resulted in a non-significant $57 \%(P=0 \cdot 051)$ reduction in non-endothelial cell proliferation in tertiary follicles and a significant $45 \%(P=0.018)$ reduction in non-endothelial cell proliferation in dominant but atretic follicles compared with late follicular controls.

\section{Effect on vasculature}

Localization of blood vessels using an endothelial cell marker in tertiary follicles is shown in Fig. 6. Large vessels were located in the outer theca while smaller vessels were observed within the vicinity of the lamina basalis. Extensive vascularization was observed in both controls (Fig. 6A) and after $\mathrm{GnRH}$ antagonist treatment between day $0-10$ (Fig. 6B) and day 5-10 (Fig. 6C) of the follicular phase. Quantitative analysis of staining (Fig. 6D) indicated that there was no difference in the extent of thecal vascularization between the groups.

There was, however, a thinning of the theca between follicles from late follicular controls and both treatment groups, with a significant $(P=0.006)$ decrease in the mean 

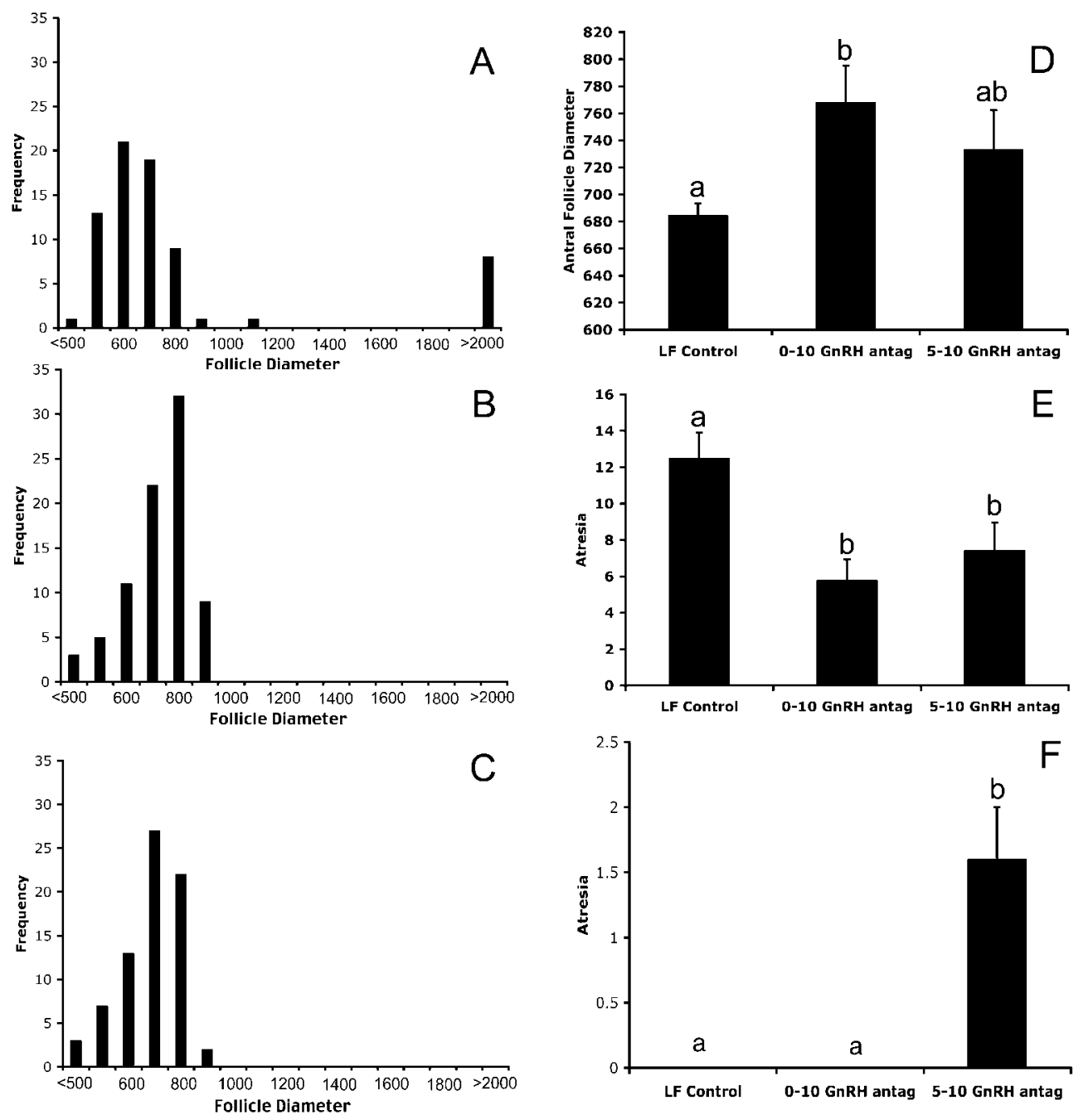

Figure 3 Histograms showing distribution of tertiary follicle size in (A) late follicular control animals, (B) days 0-10 GnRH antagonist-treated animals and (C) day 5-10 GnRH-treated animals. The effect of both the treatments was to positively skew the frequency of antral follicles present in the ovaries compared with controls, with (D) a significant increase in the mean tertiary follicle diameter between day 0-10-treated animals and controls and (E) a significant decrease in the number of atretic follicles between controls and either treatment group. (F) Number of atretic dominant follicles in controls and treated groups. Values are means \pm S.E.M. Different letters indicate statistically significant differences.

thecal thickness between dominant follicles from GnRH antagonist treatment between day 5-10 of the follicular phase and dominant follicles from late follicular controls (Fig. 6E). To adjust for the effect of the thinner theca, a conversion factor was used to quantify an absolute value of CD31-positive staining in each class of follicle, based on a technique applied by Wulff et al. (2001a). The conversion factors were calculated as a ratio of mean thecal thickness against the late follicular control mean for each class of follicle, giving the late follicular control conversion a value of one. After adjustment for thecal thickness a significant $(P=0 \cdot 04)$ reduction in thecal vascularization was demonstrated between tertiary follicles from late follicular con- trols and day $0-10 \mathrm{GnRH}$ antagonist treatment (Fig. 6F). A significant reduction $(P=0 \cdot 014)$ was also observed between dominant follicles after day 5-10 GnRH antagonist treatment and late follicular controls after adjustment for thecal thickness (Fig. 6F).

\section{Localization of VEGF $m R N A$}

In situ hybridization revealed that VEGF mRNA in both control and treated groups was absent in primordial, primary and early secondary follicles. VEGF mRNA was expressed in the granulosa of late secondary and tertiary follicles from late follicular controls (Fig. 7A and B), after 

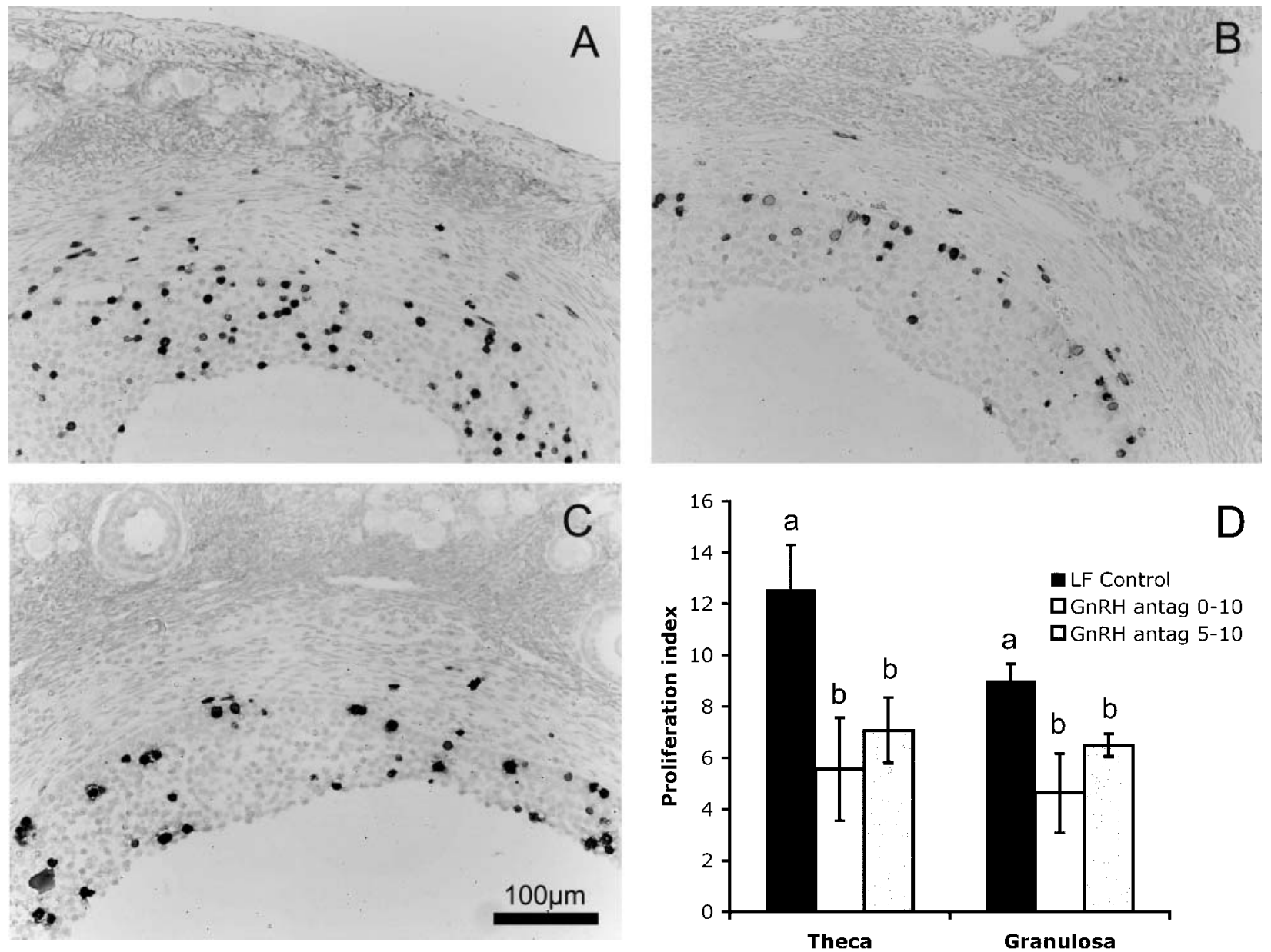

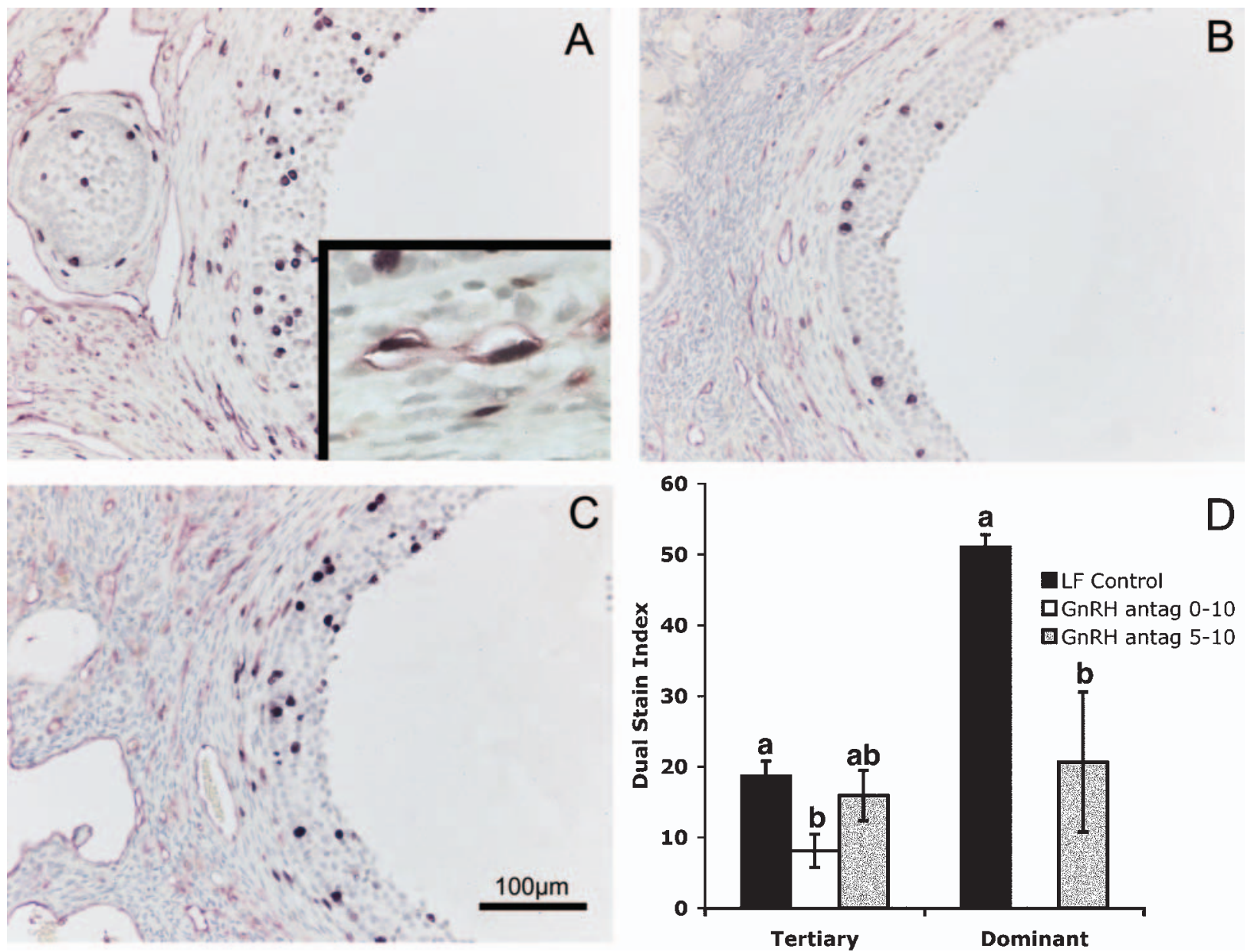

Figure 5 Photomicrographs showing dual staining of proliferating endothelial cells (black nuclei and red cell surface). (A) Control (dual stain shown in inset), (B) days 0-10 and (C) day 5-10 GnRH antagonist treatment. (D) Quantification showing that there was a significant reduction in the number of proliferating endothelial cells between controls and GnRH antagonist treatment between day 0-10. Different letters indicate statistically significant differences.

GnRH antagonist treatment between day 0-10 (Fig. 7E and $\mathrm{F}$ ) and day 5-10 (Fig. 7G and $\mathrm{H}$ ) and in mid follicular controls (Fig. 7I and 7J). VEGF mRNA was also expressed in the theca of atretic follicles in the late follicular controls (Fig. 7C and D). However, thecal expression was absent in the theca of atretic follicles from either of the treatment groups and the mid follicular controls (Fig. 7E-J).

In the dominant follicles of late follicular controls, VEGF mRNA continued to be expressed in the granulosa cells (Fig. 8A and B). However, in follicles that appeared to be closer to the time of ovulation, VEGF mRNA expression in the granulosa cells was reduced and an intense punctate expression pattern in cells in the thecal layer on the border of the granulosa cells was observed (Fig. 8C and D). This punctate pattern was also observed in postovulatory follicles (Fig. 8E and F) at the edge of the newly forming corpus luteum.
In contrast, VEGF mRNA expression was absent from both granulosa and theca in all the dominant follicles from the day 5-10 GnRH antagonist treatment group (Fig. 8G and $\mathrm{H}$ ). Quantitative analysis confirmed these observations (Fig. 9A and B).

\section{Aromatase $m R N A$}

Aromatase mRNA expression was measured to establish the level of differentiation of the granulosa cells. In control preovulatory follicles, aromatase mRNA was expressed in the mural granulosa cells closest to the membrana propria (Fig. 10A and B), along with some expression in old luteal tissue and newly forming extra-luteal tissue. After both the GnRH antagonist treatment regimes there was an absence of aromatase mRNA expression (day 5-10 shown 

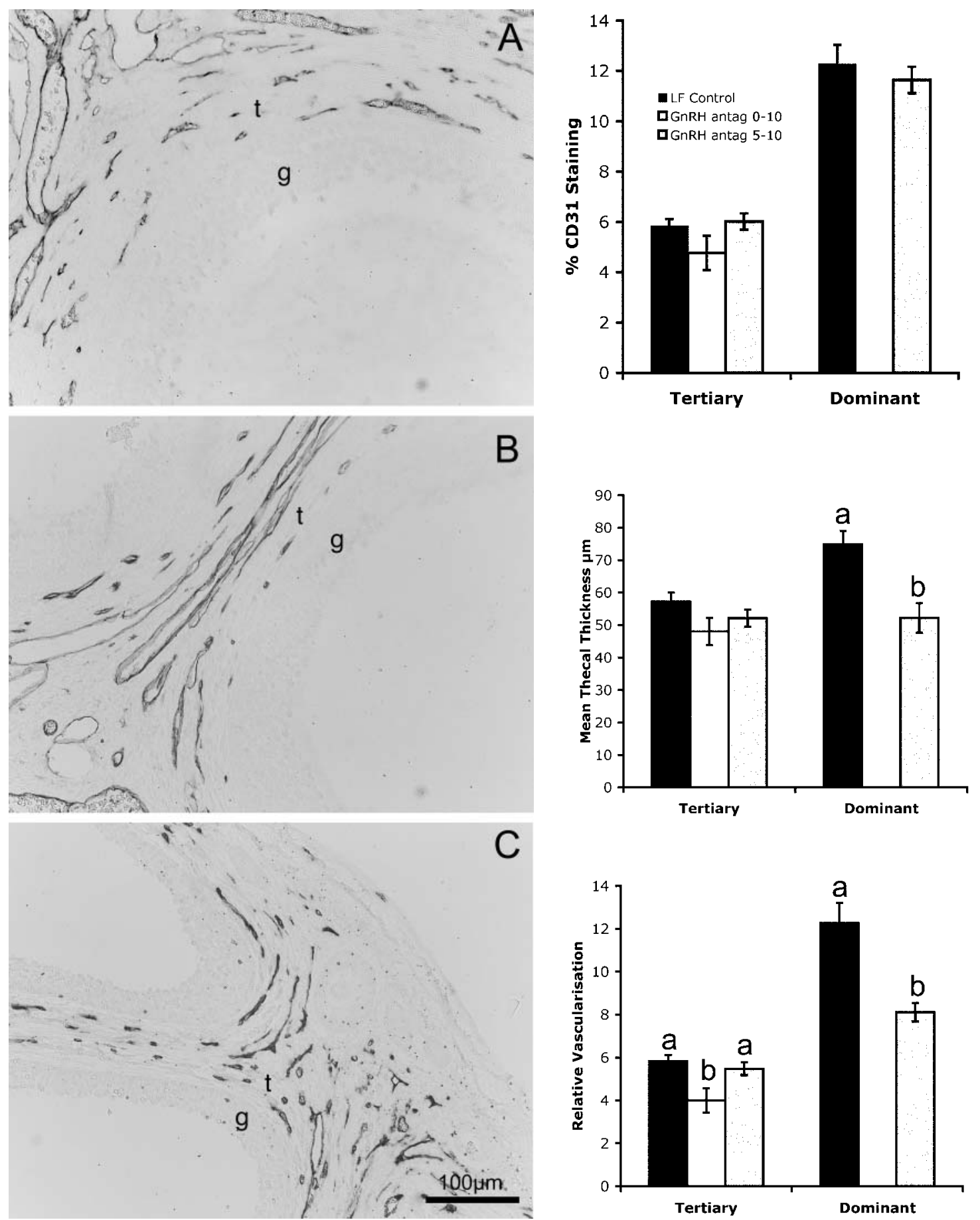

Figure 6 Photomicrographs of tertiary follicles stained for CD31 to visualize endothelial cells. (A) A tertiary follicle from control, (B) day 0-10 and (C) day 5-10 GnRH antagonist-treated ovaries. Note the uniformity between the control and treatment groups. (D) Quantitative analyses confirmed the observation of uniform vascularization between the control and treated groups. Measurement is the percentage CD31-positive staining divided by the total area of the thecal compartment. (E) Measurement of mean thecal thickness between control and treated groups revealed a significant reduction between day 0-10-treated and control ovaries. $t$, theca; g, granulosa. (F) Quantification of endothelial area between control and treated groups after conversion by the ratio of mean thecal thickness. 

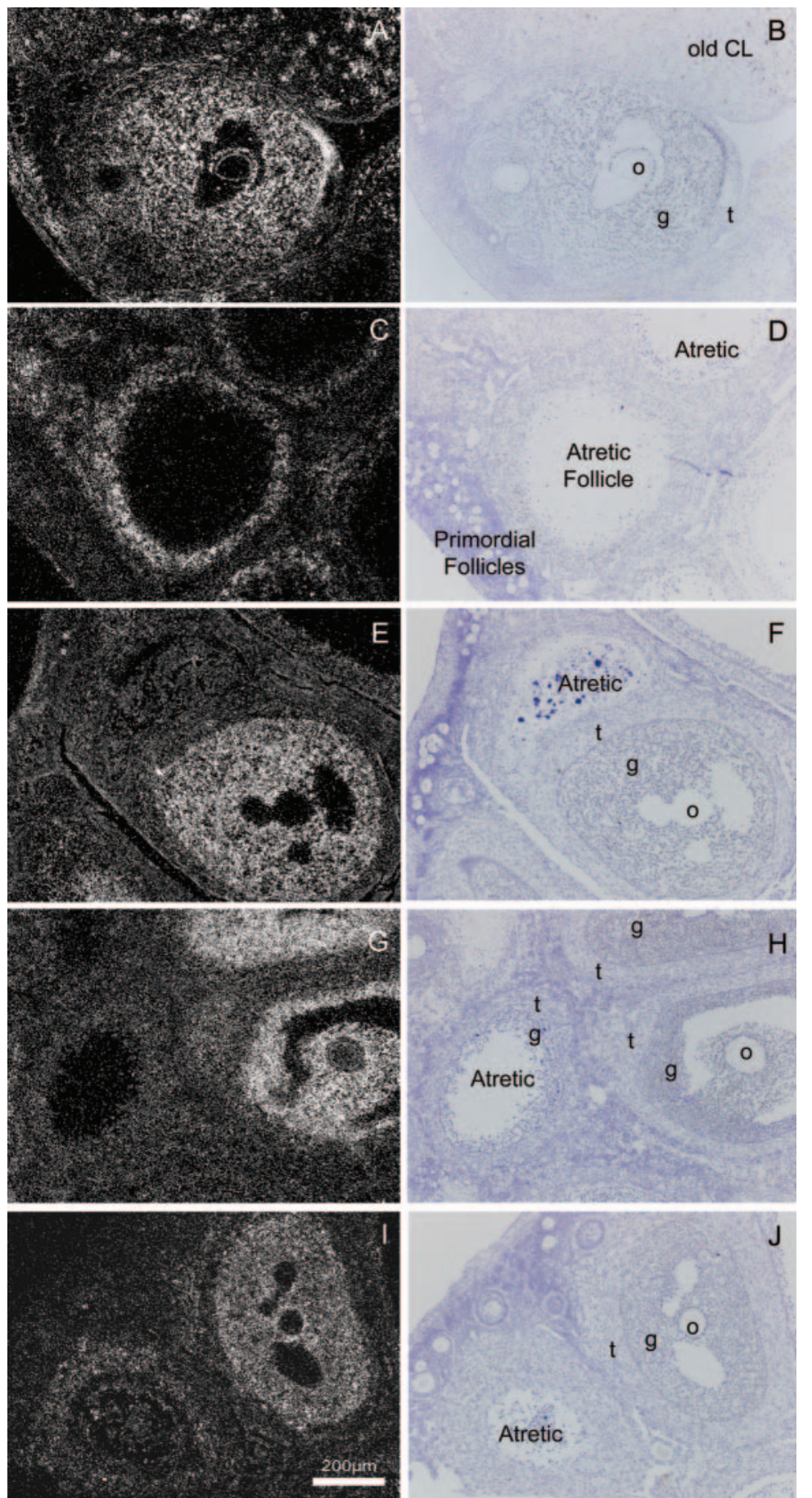

Figure 7 Dark and light field photomicrographs showing in situ hybridization for VEGF mRNA. (A and B) VEGF mRNA localized in the granulosa (g) of late follicular phase tertiary follicles. The same expression pattern was found in both treatment groups, $(\mathrm{E}$ and $\mathrm{F})$ day $0-10,(\mathrm{G}$ and $\mathrm{H})$ day $5-10$ and ( $\mathrm{I}$ and $\mathrm{J})$ in mid follicular controls. VEGF mRNA was also expressed in the theca $(\mathrm{t})$ of atretic follicles in the late follicular controls (C and D) but was absent in atretic follicles in both of the treatment groups and the mid follicular controls (E-J). Note the frequent occurrence of high expression in cumulus cells surrounding oocyte (o). 

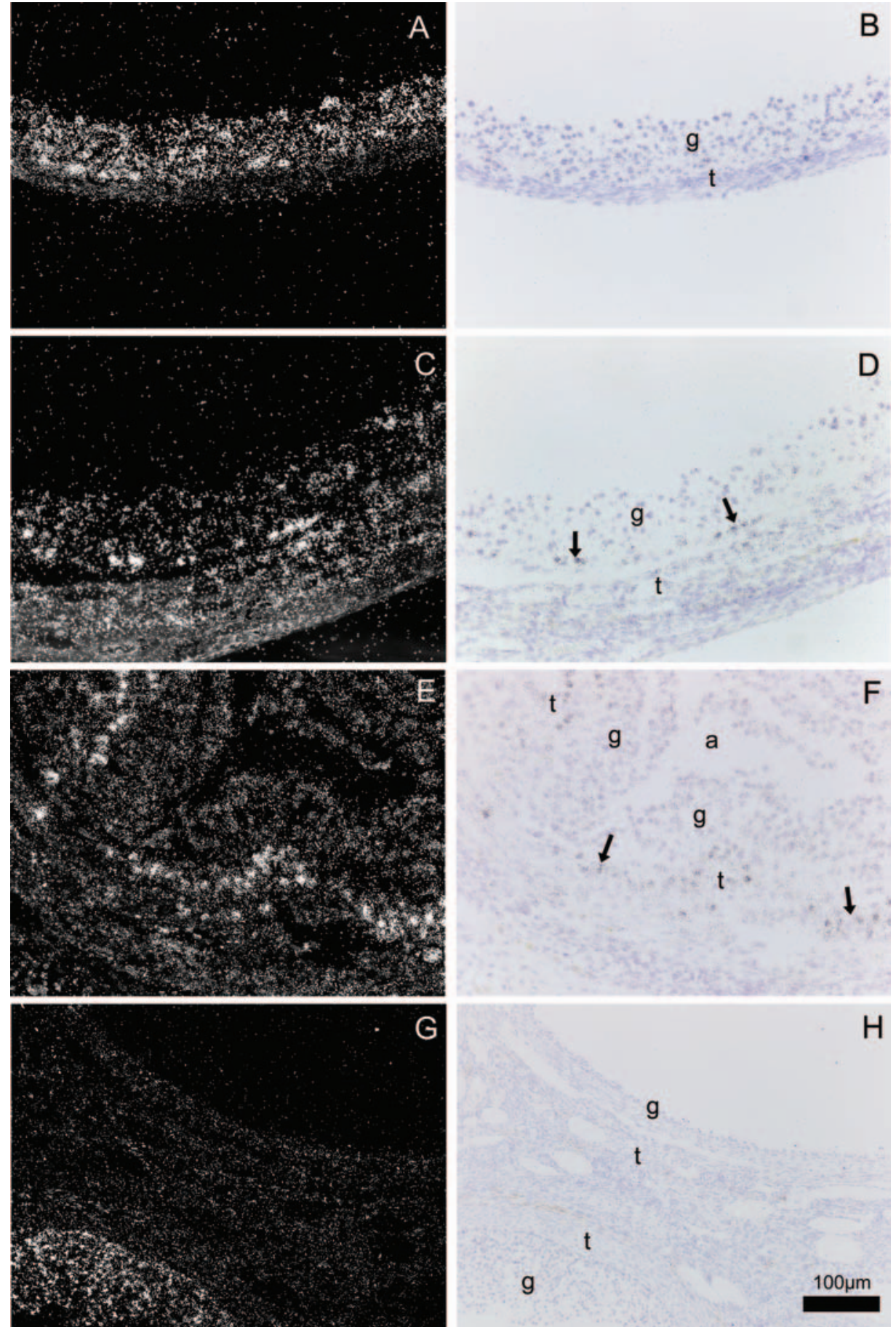

Figure 8 Dark and light field photomicrographs showing in situ hybridization for VEGF mRNA. (A and

B) VEGF mRNA localized in the dominant follicles of late follicular controls. VEGF mRNA is expressed in the granulosa cells (g). (C and D) Before ovulation, VEGF mRNA expression in the granulosa cells is reduced while a punctate expression pattern in the theca cells $(\mathrm{t})$ on the border of the granulosa cells is observed (arrows). ( $\mathrm{E}$ and $\mathrm{F}$ ) This punctate pattern is also observed in postovulatory follicles at the edge of the newly forming corpus luteum (arrows). ( $\mathrm{G}$ and $\mathrm{H}$ ) This expression is absent in the dominant follicles from the day 5-10 $\mathrm{GnRH}$ antagonist treatment group while expression is maintained in the granulosa of tertiary follicles. 

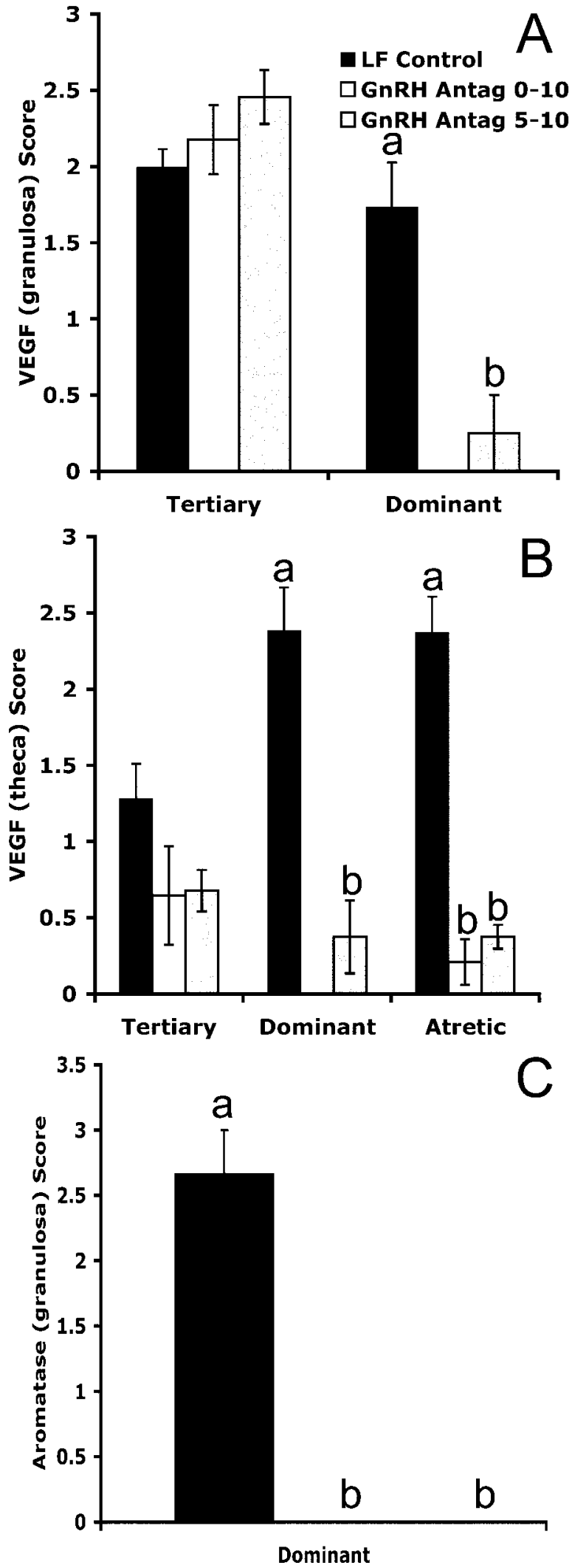

in Fig. 10C and D). Some expression in old luteal tissue was maintained. Quantitative analysis confirmed this observation (Fig 9C).

\section{Discussion}

GnRH antagonists are widely used in the clinic during ovarian hyperstimulation programmes to block endogenous gonadotrophin secretion and the preovulatory $\mathrm{LH}$ surge while exogenous gonadotrophins are being administered (Huirne et al. 2004). Many studies have examined the effects of GnRH antagonist treatment on pituitaryovarian function throughout the follicular phase in nonhuman primates and in women and demonstrated a suppression in LH and FSH secretion associated with a fall in serum oestradiol production (Ditkoff et al. 1991, Fluker et al. 1991, Hall et al. 1991, Karnitis et al. 1994, Nelson et al. 1995, Fraser et al. 1999b). However, the effect upon vascularization of the follicles during $\mathrm{GnRH}$ antagonist treatment has not been determined. In a previous study, we have shown that GnRH antagonist treatment of marmosets during the early luteal phase had a marked inhibitory effect upon the intense angiogenesis normally observed in the corpus luteum at this time (Dickson \& Fraser 2000) and that this was associated with luteal cellular degeneration (Dickson \& Fraser 2000) and a marked reduction in expression of VEGF as demonstrated by in situ hybridization (H M Fraser, unpublished observations).

Angiogenesis is intimately involved in ovarian follicle development (Fraser \& Wulff 2001, Zimmermann et al. 2001, 2003) and is necessary for normal follicular growth (Wulff et al. 2001b, 2002). The expression pattern of VEGF mRNA in the ovarian follicle suggests that it is regulated by gonadotrophic stimulation (Ravindranath et al. 1992, Shweiki et al. 1993). Hence the effect of $\mathrm{GnRH}$ antagonist treatment on follicular development and vascularization in the marmoset ovary might be expected to result in a suppression of VEGF expression, inhibition of angiogenesis and follicular development. However, the results revealed that the links between $\mathrm{GnRH}$, follicular VEGF expression and angiogenesis are more tenuous than for the early corpus luteum.

The most expected findings were observed in the day 0-10 GnRH antagonist-treated animals in which development of large dominant follicles was completely inhibited and oestradiol secretion was markedly suppressed. In the remaining healthy tertiary follicles, granulosa and theca

Figure 9 Quantification of in situ hybridization. (A) VEGF mRNA in granulosa cells of tertiary and dominant follicles. (B) VEGF mRNA in thecal compartment of tertiary, dominant and atretic follicles. (C) Aromatase mRNA expression in the granulosa cells of dominant follicles. Values are means \pm S.E.M. Different letters indicate statistically significant differences. 

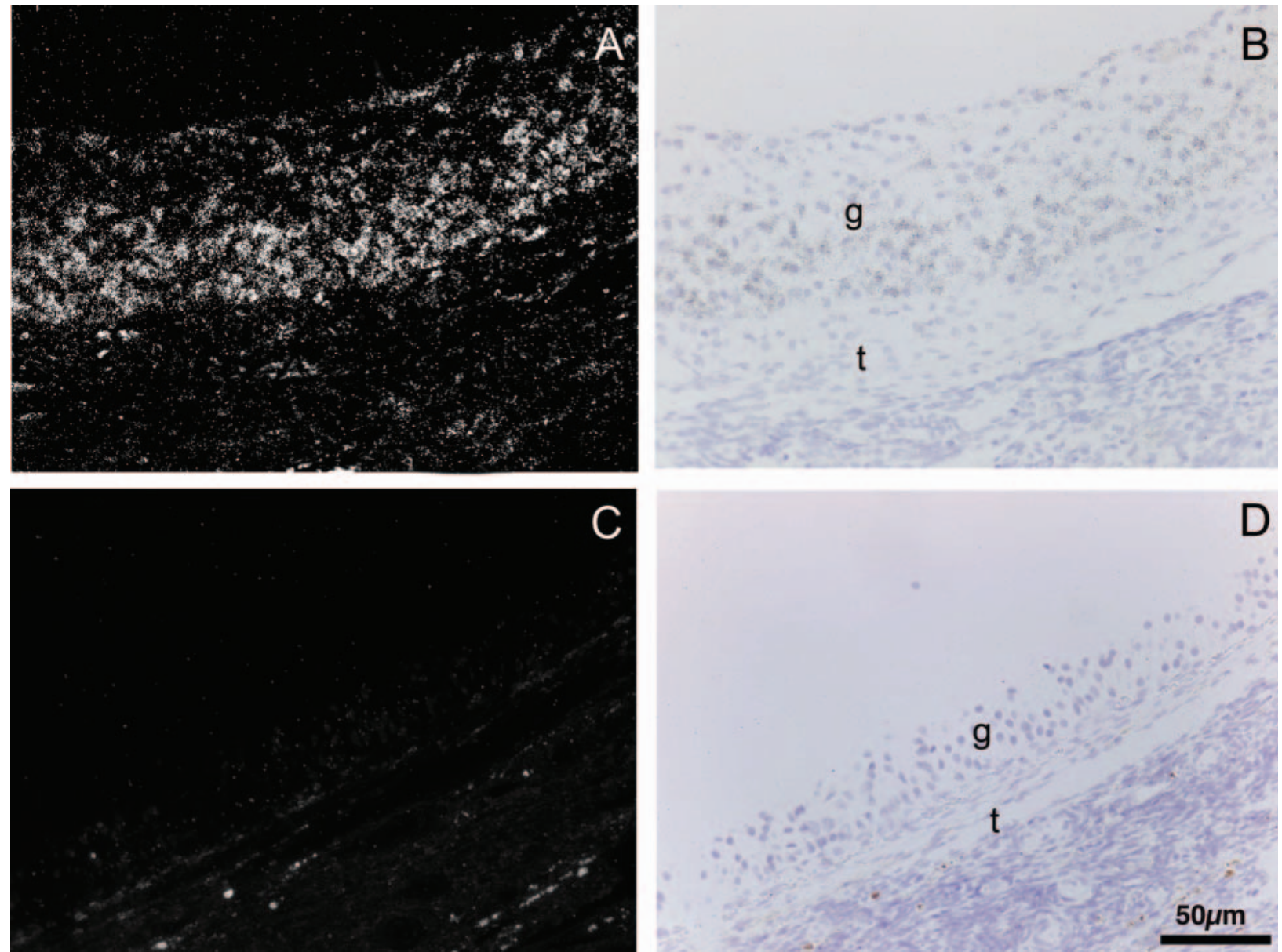

Figure 10 Photomicrograph of in situ hybridization for aromatase mRNA. (A and B) Aromatase in situ in a preovulatory follicle and (C and D) day 5-10 GnRH antagonist treated. Note the absence of aromatase mRNA expression in the treated ovary. $t$, theca; $g$, granulosa.

cell proliferation was reduced. Angiogenesis was also lower in these follicles and this resulted in a reduction in endothelial cell area after the reduction in thecal thickness was taken into account. However, these effects were much less than after inhibition of VEGF by a specific antagonist (Wulff et al. 2002). Surprisingly, VEGF mRNA expression was similar to controls in these tertiary follicles. Similarly, in the days 5-10-treated group, VEGF mRNA continued to be highly expressed in the granulosa cells of tertiary follicles. This suggested that, at this stage of development, follicular VEGF expression is not tightly controlled by the gonadotrophins. It is reasonable to suggest that expression may be maintained by residual gonadotrophin secretion. Unfortunately $\mathrm{LH}$ and FSH could not be measured in the present study because these assays are problematic in the marmoset and there are restrictions in the volume of plasma that can be collected. However, a degree of residual level of gonadotrophin secretion would be expected to persist after GnRH antagonist treatment, with FSH being less suppressed than LH (Ditkoff et al. 1991, Fluker et al. 1991, Hall et al. 1991, Nelson et al. 1995, Oberye et al. 1999). While this suppression is sufficient to reduce the ability of mature follicles to produce oestradiol, the low levels of LH and FSH remaining may be sufficient to maintain the activity of tertiary follicles. In addition, the possibility of stimulation of VEGF expression by hypoxia, as seen in solid tumours (Shweiki et al. 1992) and the endometrium (Sharkey et al. 2000), occurring in granulosa cells in tertiary follicles deprived of gonadotrophic support requires to be investigated. However, this phenomenon does not appear to occur in follicular granulosa cells from preovulatory follicles (Martinez-Chequer et al. 2003). Paracrine mechanisms could also be acting in these tertiary follicles that may still function during the withdrawal of the gonadotrophins to help maintain VEGF mRNA expression. Recent evidence also suggests that locally produced factors and cytokines such as insulin-like growth 
factors-I and -II play a role in regulating ovarian VEGF mRNA expression in preovulatory follicles (MartinezChequer et al. 2003). Such mechanisms may also explain the continued VEGF mRNA expression in tertiary follicles in the current study. The fact that there was a decrease in endothelial cell proliferation in these follicles after 10 days of $\mathrm{GnRH}$ antagonist treatment does suggest that a deleterious effect on the VEGF pathway was occurring, perhaps at the level of translation of VEGF mRNA into biologically active protein or by disruption of the process of transfer of the VEGF protein from the granulosa cells to the thecal layer.

Although preovulatory follicles developed during treatment with $\mathrm{GnRH}$ antagonist between day 5-10, these follicles were abnormal and cystic in appearance. This indicates a stage of development after which normal levels of gonadotrophic support for follicle expansion is not required, presumably because the dominant follicles have already been selected by the mid follicular phase, as suggested by Gilchrist et al. (2001). Angiogenesis was decreased in these cyst-like follicles and VEGF mRNA was absent from both the theca and the granulosa cell layers. The observation that follicles grew to preovulatory size but undergo atresia and fail to produce oestradiol indicates a differential level of gonadotrophic stimulation required for proliferation (growth) and cellular differentiation (steroid synthesis) in the dominant follicle. In addition, the marked reduction in aromatase mRNA expression in these dominant but atretic follicles gives further support to the hypothesis that a differential level of gonadotrophic support is required for dominant follicle expansion and differentiation. GnRH antagonist treatment in cynomolgus monkeys has shown that FSH alone is capable of stimulating follicle expansion as determined by ultrasound monitoring, whilst not stimulating oestradiol production due to lack of LH-stimulated androgen production (Karnitis et al. 1994), although the health of these large follicles was not assessed.

It might have been expected that the rate of follicular atresia would have increased after GnRH antagonist treatment. However, there was a reduction in the number of atretic follicles and an increase in the mean tertiary follicle diameter after both GnRH antagonist treatment schedules. This may be explained by the fact that tertiary follicles not having sufficient FSH stimulation to continue developing appear to be held in an arrested state of development and fail to be cleared from the ovary by apoptosis (Tsafriri \& Braw 1984) as they would be in a normal follicular phase ovary approaching ovulation. Also, the reduction in thecal thickness observed in the dominant follicle from the day 5-10 treatment group is probably due to a deficiency in gonadotrophic support for both the theca directly and the granulosa cells stimulating thecal development in a paracrine manor.

In follicles close to the point of ovulation in control ovaries, a shift in the VEGF mRNA expression pattern was observed, disappearing from the granulosa cells but switching on in an intense punctate pattern in the theca in cells close to the blood vessels. In healthy preovulatory follicles, the reduction in VEGF mRNA expression was consistent with the finding that VEGF production is switched off in the granulosa cells of gilts after treatment with human chorionic gonadotrophin (Barboni et al. 2000). The punctate VEGF mRNA expression observed in the thecal compartment of dominant follicles on follicular day 10 in the marmoset appears to be similar to that first noted in the rhesus monkey ovary (Ravindranath et al. 1992). It has also been suggested from observations in the sheep ovary that pericytes in the thecal layer play a key role in the transition from preovulatory follicle to the new corpus luteum (Redmer et al. 2001). The VEGF mRNA-positive cells observed in the marmoset theca are possibly vascular pericytes. However, these conclusions do not appear to concur with other studies on expression of VEGF mRNA and protein in the rhesus monkey (Christenson \& Stouffer 1997, Hazzard et al. 1999), where cultures of aspirated granulosa cells exposed to regimes of FSH and LH in vivo showed that VEGF expression is stimulated by the gonadotrophins.

The absence of VEGF mRNA expression in the theca of atretic dominant follicles from the days 5-10 GnRH antagonist-treated group indicates that the expression of VEGF in the thecal cells directly prior to ovulation is dependent upon the LH surge and not hypoxia as suggested by Neeman et al. (1997). The LH surge is absent in both GnRH antagonist-treated groups, while the morphologically intact theca of these follicles would still be responsive to $\mathrm{LH}$. The absence of VEGF mRNA expression in the dominant atretic follicles from the day $5-10$ GnRH antagonist-treated group also suggests that normal physiological levels of VEGF are not required for dominant follicle expansion between the mid to late follicular period, even though VEGF is thought to play a role as a permeability factor in follicle development (Koos 1995), allowing the movement of fluid into the follicle to expand the antral cavity.

Surprisingly, VEGF mRNA expression was also detected in the theca of atretic tertiary follicles in the late follicular control animals. This expression was again absent in $\mathrm{GnRH}$ antagonist-treated animals and was not present in atretic follicles from mid follicular phase ovaries. This suggests that the LH surge triggers the strong expression of VEGF mRNA in the theca of atretic follicles at the time of ovulation, which may play a role in the establishment of extra luteal tissue from the atretic tertiary follicles present at ovulation, a common feature in the marmoset (McAnulty 1994).

It is of interest to compare the current results with the effects of specific targeting of VEGF on follicular angiogenesis and development in the marmoset. A much higher degree of inhibition of angiogenesis and follicular development was observed when directly inhibiting VEGF 
with a potent, receptor-based antagonist VEGF Trap R1R2 (Wulff et al. 2002). This antagonist binds VEGF with high affinity and prevents it reaching its receptors. Thus, no matter what compensatory mechanisms come into operation to restore VEGF, they are negated by the VEGF inhibitor. In contrast, while treatment with GnRH antagonist inhibits gonadotrophin secretion this may have little effect on the ability of hypoxia and local paracrine mechanisms to mediate or modulate VEGF action in the ovarian follicle, as these compensatory mechanisms may be allowed to function. It follows that the reason that $\mathrm{GnRH}$ antagonist treatment is more effective in suppressing early luteal angiogenesis (Dickson \& Fraser 2000) is likely to be because the corpus luteum is heavily dependent upon LH (Fraser et al. 1986). This dependence would include the local compensatory mechanisms that are relatively gonadotrophin independent in the developing follicle.

In conclusion, the use of a GnRH antagonist to block gonadotrophin release did not result in complete inhibition of follicular angiogenesis and vascularization and raises the possibility of other factors and paracrine mechanisms regulating VEGF and angiogenesis in the primate ovarian follicle.

\section{Acknowledgements}

We thank K Morris and staff for animal care, Dr R Deghenghi, Europeptides, for the gift of Antarelix, Dr C Wulff for discussions, F Pitt and I Swanston for the hormone assays and T Pinner for graphical support. S G H acknowledges programme grant support from the MRC (PG0000066).

\section{References}

Barboni B, Turriani M, Galeati G, Spinaci M, Bacci ML, Forni M \& Mattioli M 2000 Vascular endothelial growth factor production in growing pig antral follicles. Biology of Reproduction 63 858-864.

Christenson LK \& Stouffer RL 1997 Follicle-stimulating hormone and luteinizing hormone/chorionic gonadotropin stimulation of vascular endothelial growth factor production by macaque granulosa cells from pre- and periovulatory follicles. Journal of Clinical Endocrinology and Metabolism 82 2135-2142.

Deghenghi R, Boutignon F, Wuthrich P \& Lenaerts V 1993 Antarelix (EP 24332) a novel water soluble LHRH antagonist. Biomedical Pharmacotherapy 47 107-110.

Dickson SE \& Fraser HM 2000 Inhibition of early luteal angiogenesis by gonadotropin-releasing hormone antagonist treatment in the primate. Journal of Clinical Endocrinology and Metabolism $\mathbf{8 5}$ 2339-2344.

Ditkoff EC, Cassidenti DL, Paulson RJ, Sauer MV, Paul WL, Rivier J, Yen SS \& Lobo RA 1991 The gonadotropin-releasing hormone antagonist (Nal-Glu) acutely blocks the luteinizing hormone surge but allows for resumption of folliculogenesis in normal women. American Journal of Obstetrics and Gynecology 165 1811-1817.

Durlinger AL, Kramer P, Karels B, Grootegoed JA, Uilenbroek JT \& Themmen AP 2000 Apoptotic and proliferative changes during induced atresia of pre-ovulatory follicles in the rat. Human Reproduction 15 2504-2511.
Fluker MR, Marshall LA, Monroe SE \& Jaffe RB 1991 Variable ovarian response to gonadotropin-releasing hormone antagonist-induced gonadotropin deprivation during different phases of the menstrual cycle. Journal of Clinical Endocrinology and Metabolism 72 912-919.

Fraser HM \& Wulff C 2001 Angiogenesis in the primate ovary. Reproduction, Fertility and Development 13 557-566.

Fraser HM, Abbott M, Laird NC, McNeilly AS, Nestor JJ Jr \& Vickery BH 1986 Effects of an LH-releasing hormone antagonist on the secretion of $\mathrm{LH}, \mathrm{FSH}$, prolactin and ovarian steroids at different stages of the luteal phase in the stumptailed macaque (Macaca arctoides). Journal of Endocrinology 111 83-90.

Fraser HM, Dickson SE, Morris KD, Erickson GF \& Lunn SF 1999a The effect of the angiogenesis inhibitor TNP-470 on luteal establishment and function in the primate. Human Reproduction $\mathbf{1 4}$ 2054-2060.

Fraser HM, Groome NP \& McNeilly AS 1999b Follicle-stimulating hormone-inhibin $\mathrm{B}$ interactions during the follicular phase of the primate menstrual cycle revealed by gonadotropin-releasing hormone antagonist and antiestrogen treatment. Journal of Clinical Endocrinology and Metabolism 84 1365-1369.

Fraser HM, Dickson SE, Lunn SF, Wulff C, Morris KD, Carroll VA \& Bicknell R 2000 Suppression of luteal angiogenesis in the primate after neutralization of vascular endothelial growth factor. Endocrinology 141 995-1000.

Gilchrist RB, Wicherek M, Heistermann M, Nayudu PL \& Hodges JK 2001 Changes in follicle-stimulating hormone and follicle populations during the ovarian cycle of the common marmoset. Biology of Reproduction 64 127-135.

Hall JE, Bhatta N, Adams JM, Rivier JE, Vale WW \& Crowley WF Jr 1991 Variable tolerance of the developing follicle and corpus luteum to gonadotropin-releasing hormone antagonist-induced gonadotropin withdrawal in the human. Journal of Clinical Endocrinology and Metabolism 72 993-1000.

Hazzard TM, Molskness TA, Chaffin CL \& Stouffer RL 1999 Vascular endothelial growth factor (VEGF) and angiopoietin regulation by gonadotrophin and steroids in macaque granulosa cells during the peri-ovulatory interval. Molecular Human Reproduction $\mathbf{5}$ $1115-1121$.

Huirne JA, Lambalk CB, van Loenen AC, Schats R, Hompes PG, Fauser BC \& Macklon NS 2004 Contemporary pharmacological manipulation in assisted reproduction. Drugs 64 297-322.

Karnitis VJ, Townson DH, Friedman CI \& Danforth DR 1994 Recombinant human follicle-stimulating hormone stimulates multiple follicular growth, but minimal estrogen production in gonadotropin-releasing hormone antagonist-treated monkeys: examining the role of luteinizing hormone in follicular development and steroidogenesis. Journal of Clinical Endocrinology and Metabolism 79 91-97.

Koos RD 1995 Increased expression of vascular endothelial growth/permeability factor in the rat ovary following an ovulatory gonadotropin stimulus: potential roles in follicle rupture. Biology of Reproduction 52 1426-1435.

McAnulty PA 1994 Marmoset care and reproduction. In The Marmoset - Role in Pharmacentical Development, pp. 7-12. Ed. JS Fowler. Ipswich: Pharmaco LSR.

Mann GE, Lamming GE \& Fray MD 1995 Plasma oestradiol and progesterone during early pregnancy in the cow and the effects of treatment with buserelin. Animal Reproduction Science 37 121-131.

Martinez-Chequer JC, Stouffer RL, Hazzard TM, Patton PE \& Molskness TA 2003 Insulin-like growth factors-1 and -2, but not hypoxia, synergize with gonadotropin hormone to promote vascular endothelial growth factor - A secretion by monkey granulosa cells from preovulatory follicles. Biology of Reproduction 68 1112-1118.

Neeman M, Abramovitch R, Schiffenbauer YS \& Tempel C 1997 Regulation of angiogenesis by hypoxic stress: from solid tumours to the ovarian follicle. International Journal of Experimental Pathology $\mathbf{7 8}$ $57-70$. 
Nelson LR, Fujimoto VY, Jaffe RB \& Monroe SE 1995 Suppression of follicular phase pituitary-gonadal function by a potent new gonadotropin-releasing hormone antagonist with reduced histaminereleasing properties (ganirelix). Fertility and Sterility 63 963-969.

Oberye JJ, Mannaerts BM, Huisman JA \& Timmer CJ 1999 Pharmacokinetic and pharmacodynamic characteristics of ganirelix (Antagon/Orgalutran). Part II. Dose-proportionality and gonadotropin suppression after multiple doses of ganirelix in healthy female volunteers. Fertility and Sterility 72 1006-1012.

Phillips HS, Hains J, Leung DW \& Ferrara N 1990 Vascular endothelial growth factor is expressed in rat corpus luteum. Endocrinology 127 965-967.

Ravindranath N, Little-Ihrig L, Phillips HS, Ferrara N \& Zeleznik AJ 1992 Vascular endothelial growth factor messenger ribonucleic acid expression in the primate ovary. Endocrinology 131 254-260.

Redmer DA, Doraiswamy V, Bortnem BJ, Fisher K, Jablonka-Shariff A, Grazul-Bilska AT \& Reynolds LP 2001 Evidence for a role of capillary pericytes in vascular growth of the developing ovine corpus luteum. Biology of Reproduction 65 879-889.

Sharkey AM, Day K, McPherson A, Malik S, Licence D, Smith SK \& Charnock-Jones DS 2000 Vascular endothelial growth factor expression in human endometrium is regulated by hypoxia. Journal of Clinical Endocrinology and Metabolism 85 402-409.

Shweiki D, Itin A, Soffer D \& Keshet E 1992 Vascular endothelial growth factor induced by hypoxia may mediate hypoxia-initiated angiogenesis. Nature 359 843-845.

Shweiki D, Itin A, Neufeld G, Gitay-Goren H \& Keshet E 1993 Patterns of expression of vascular endothelial growth factor (VEGF) and VEGF receptors in mice suggest a role in hormonally regulated angiogenesis. Journal of Clinical Investigation 91 2235-2243.

Tsafriri A \& Braw RH 1984 Experimental approaches to atresia in mammals. Oxford Reviews of Reproductive Biology 6 226-265.

Wulff C, Dickson SE, Duncan WC \& Fraser HM 2001a Angiogenesis in the human corpus luteum: simulated early pregnancy by HCG treatment is associated with both angiogenesis and vessel stabilization. Human Reproduction 16 2515-2524.
Wulff C, Wiegand SJ, Saunders PT, Scobie GA \& Fraser HM $2001 b$ Angiogenesis during follicular development in the primate and its inhibition by treatment with truncated Flt-1-Fc (vascular endothelial growth factor Trap(A40)). Endocrinology 142 3244-3254.

Wulff C, Wilson H, Rudge JS, Wiegand SJ, Lunn SF \& Fraser HM 2001c Luteal angiogenesis: prevention and intervention by treatment with vascular endothelial growth factor trap(A40). Journal of Clinical Endocrinology and Metabolism 86 3377-3386.

Wulff C, Wilson H, Wiegand SJ, Rudge JS \& Fraser HM 2002 Prevention of thecal angiogenesis, antral follicular growth, and ovulation in the primate by treatment with vascular endothelial growth factor Trap R1R2. Endocrinology 143 2797-2807.

Zeleznik AJ, Schuler HM \& Reichert LE Jr 1981 Gonadotropin-binding sites in the rhesus monkey ovary: role of the vasculature in the selective distribution of human chorionic gonadotropin to the preovulatory follicle. Endocrinology 109 356-362.

Zimmermann RC, Xiao E, Husami N, Sauer MV, Lobo R, Kitajewski J \& Ferin M 2001 Short-term administration of antivascular endothelial growth factor antibody in the late follicular phase delays follicular development in the rhesus monkey. Journal of Clinical Endocrinology and Metabolism 86 768-772.

Zimmermann RC, Xiao E, Bohlen P \& Ferin M 2002 Administration of antivascular endothelial growth factor receptor 2 antibody in the early follicular phase delays follicular selection and development in the rhesus monkey. Endocrinology 143 2496-2502.

Zimmermann RC, Hartman T, Kavic S, Pauli SA, Bohlen P, Sauer MV \& Kitajewski J 2003 Vascular endothelial growth factor receptor 2-mediated angiogenesis is essential for gonadotropin-dependent follicle development. Journal of Clinical Investigation 112 659-669.

Received in final form 29 June 2004

Accepted 14 July 2004 